\title{
IMPAIRMENT OF RENAL FUNCTION WITH INCREASING BLOOD LEAD CONCENTRATIONS IN THE GENERAL POPULATION
}

\author{
Jan A. Staessen, M.D., Ph.D., Robert R. Lauwerys, M.D., Ph.D., Jean-Pierre Bughet, Ph.D., \\ Christopher J. Bulpitt, M.D., M.Sc., Désiré Rondia, Ph.D., Yves Vanrenterghem, M.D., Ph.D., \\ Antoon Amery, M.D., Ph.D., and the Cadmibel Study Group*
}

\begin{abstract}
Background. Nephropathy is known to occur in persons with heavy exposure to lead. Whether exposure to lead in the general population leads to impaired renal function is not known.

Methods. We studied renal function and indexes of lead exposure in a random population sample of 965 men and 1016 women (age range, 20 to 88 years). In all the subjects we measured creatinine clearance and blood concentrations of lead and zinc protoporphyrin (an indirect measure of blood lead level).

Results. The mean $( \pm S D)$ creatinine clearance rate was $99 \pm 30 \mathrm{ml}$ per minute in the men and $80 \pm 25 \mathrm{ml}$ per minute in the women. In the men the geometric mean blood lead concentration was $114 \mu \mathrm{g}$ per liter $(0.55 \mu \mathrm{mol}$ per liter) (range, 23 to $725 \mu \mathrm{g}$ per liter [0.11 to $3.5 \mu \mathrm{mol}$ per liter]), and in the women $75 \mu \mathrm{g}$ per liter ( $0.36 \mu \mathrm{mol}$ per liter) (range, 17 to $603 \mu \mathrm{g}$ per liter [0.08 to $2.9 \mu \mathrm{mol}$ per liter]); the zinc protoporphyrin values in blood averaged 1.0 and
\end{abstract}

CADMIUM ${ }^{1}$ and lead ${ }^{2}$ are toxic to the kidney. 1 Both metals are known to induce nephropathy in subjects with heavy exposure. ${ }^{1,2}$ Environmental exposure to cadmium is associated with renal tubular dysfunction, ${ }^{3}$ but few studies have attempted to evaluate the renal effects of environmental lead exposure. A weak positive correlation between serum creatinine and blood lead concentrations was found in men, but not women, in the British civil service. ${ }^{4}$

We investigated the relation between lead exposure and renal function in the general population, using data obtained during the Cadmibel (Cadmium in Belgium) Study. ${ }^{3}$ Lead exposure was estimated by measuring blood concentrations of lead and zinc protoporphyrin, ${ }^{5}$ which is increased in the presence of high lead levels.

From the Hypertension and Cardiovascular Rehabilitation Unit (J.A.S., C.J.B., A.A.) and the Nephrology Unit (Y.V.), Department of Pathophysiology, University of Leuven, Leuven; the Industrial Toxicology and Occupational Medicine Unit, University of Louvain, Brussels (R.R.L., J.-P.B.); and the Environmental Toxicology Unit, University of Liege, Liege (D.R.) - all in Belgium. Address reprint requests to Dr. Staessen at the Klinisch Laboratorium Hypertensie, Inwendige Geneeskunde-Cardiologie, Universitair Ziekenhuis Gasthuisberg, Herestraat 49, B-3000 Leuven, Belgium.

Supported by the Ministry of Health and Social Affairs, the Ministry of the Flemish Community, the Ministry of the Brussels Region, and the Belgian National Fund for Medical Research (all in Brussels); the Province of Limburg (Hasselt, Belgium); and the International Lead and Zinc Research Organization (Research Triangle Park, N.C.). Dr. Staessen is also supported by the "Health Hazards" incentive program initiated by the Science Policy Office of the Prime Minister's Service, Brussels.

*The Cadmibel Study Group consisted of A. Amery, C.J. Bulpitt, R. Fagard, P. Lijnen, J.A. Staessen, and L. Thijs (Hypertension and Cardiovascular Rehabilitation Unit, Department of Pathophysiology, University of Leuven); A. Bernard, J.-P. Buchet, R.R. Lauwerys, and H. Roels (Industrial Toxicology and Occupational Medicine Unit, University of Louvain, Brussels); P. Bruaux (deceased), F. Claeys, R. De Boeck, P. De Plaen, and G. Ducoffre (Institute of Hygiene and Epidemiology, Ministry of Health and Social Affairs, Brussels); and L. Nick, A. Saint-Rémy, F. Sartor, and D. Rondia (Environmental Toxicology Unit, University of Liege).
$1.1 \mu \mathrm{g}$ per gram of hemoglobin, respectively. The creatinine clearance rate was inversely correlated with blood lead and zinc protoporphyrin values in the men and the women both before and after adjustments for age, bodymass index, and diuretic treatment. A 10-fold increase in blood lead concentration was associated with a reduction of 10 to $13 \mathrm{ml}$ per minute in creatinine clearance. We also found a positive correlation between serum $\boldsymbol{\beta}_{2}$-microglobulin (which is inversely related to the glomerular filtration rate) and blood lead in men, between serum $\beta_{2}$-microglobulin and zinc protoporphyrin in both sexes, and between serum creatinine and zinc protoporphyrin in men.

Conclusions. Exposure to lead may impair renal function in the general population. The alternative hypothesis that renal impairment may lead to an increase in the blood lead concentration cannot be excluded, however. (N Engl J Med 1992;327:151-6.)

\section{Methods}

\section{Study Population}

The Cadmibel Study ${ }^{3,5}$ was a cross-sectional population study of the health effects of environmental exposure to cadmium. In order to provide a wide range of cadmium exposure, two areas with substantial environmental exposure and two areas with lower exposure were selected on the basis of cadmium measurements in air, soil, vegetation, and ground water. ${ }^{5}$ For each level of exposure, a rural and an urban area were chosen. One urban area (Liege) was polluted as a consequence of emissions from the zinc industry, which operated until 1981, whereas the second urban area (Charleroi), where iron foundries were still in operation, was considerably less polluted with cadmium. ${ }^{5}$ The polluted rural area (Noorderkempen) was near two smelters of nonferrous metal; the rural area with low exposure (Hechtel-Eksel) was 15 to $20 \mathrm{~km}$ away. ${ }^{5}$

From 1985 to 1989 a total of 2327 subjects who were at least 20 years old, who had been living in one of the four areas for at least 8 years, and who represented a random sample of the population were recruited. The participation rate among the subjects contacted was 78 percent ( 1107 subjects) in the two rural areas, and 39 percent (1220 subjects) in the two urban areas. Among the 2327 subjects, 254 were excluded because not all relevant measurements could be obtained, 44 were excluded because their 24-hour urine samples were judged to be inaccurate on the basis of previously published criteria, ${ }^{6}$ and 48 were excluded because their occupational exposure to heavy metals (41) or smoking habits (7) could not be ascertained from a self-administered questionnaire. The study group thus totaled 1981 subjects.

The protocol was approved by the ethics committees of the four institutions taking part in the Cadmibel Study, ${ }^{3,5}$ and all the subjects gave informed consent.

\section{Field Work}

All the subjects were visited repeatedly in their homes. Blood pressure was measured five times during each of two home visits after the subjects had rested for five minutes and were sitting. The mean blood pressure, defined as the diastolic pressure plus one third of the pulse pressure, was calculated. The subjects completed a selfadministered questionnaire about their medical history, current and past occupations, smoking habits, consumption of alcohol, and intake of medications. They also collected a 24-hour urine sample in a 
wide-neck polyethylene container for the measurement of cadmium and creatinine. A sample of venous blood was obtained within two weeks after the urine collection for measurements of serum creatinine and blood lead, cadmium, and zinc protoporphyrin. In addition, the serum $\beta_{2}$-microglobulin concentration was determined as an index of glomerular filtration, ${ }^{7}$ the serum $\gamma$-glutamyl transpeptidase level as an index of alcohol intake, and the serum ferritin level as an index of iron balance.

\section{Biochemical Measurements}

We measured serum levels of creatinine, ${ }^{8} \beta_{2}$-microglobulin, ${ }^{9}$ ferritin, ${ }^{9}$ and $\gamma$-glutamyl transpeptidase, ${ }^{10}$ as well as creatinine levels in 24-hour urine specimens. ${ }^{8}$ The level of zinc protoporphyrin in blood was measured by hematofluorimetry, and lead and cadmium levels by electrothermal atomic-absorption spectrometry. ${ }^{5}$ In lead poisoning erythrocyte protoporphyrin is chelated with zinc, and therefore the zinc protoporphyrin level is an indirect measure of lead toxicity. The detection limit for blood lead was $17 \mu \mathrm{g}$ per liter $(0.08 \mu \mathrm{mol}$ per liter $)$, and for zinc protoporphyrin it was $0.2 \mu \mathrm{g}$ per gram of hemoglobin. We measured creatinine clearance directly and also calculated it on the basis of the serum creatinine concentration, using the formula proposed by Cockcroft and Gault. "I

The biochemical determinations were performed by two laboratories, but for each particular measurement all the samples were analyzed by the same laboratory. Ten percent of the lead measurements were performed by both laboratories. Assays were repeated if the difference between duplicate determinations in the same laboratory (precision) or the deviation from a given standard (accuracy) fell outside previously published limits,${ }^{5}$ or if the results in a sample differed by more than 10 percent between the two laboratories. For blood lead, we required precision within 5 percent and accuracy within 10 percent.

\section{Statistical Analysis}

We used the Statistical Analysis System (SAS Institute, Cary, N.C.) for data-base management and statistical analysis. Measurements with a skewed distribution were normalized by logarithmic transformation, and for these measurements we report the geometric mean and range.

The statistical techniques used included analysis of variance, single and multiple linear regression analysis, and logistic-regression analysis. The following variables were considered to be potential covariates of the renal measurements in multiple regression analysis: sex, age, the square of the age, body-mass index (the weight in kilograms divided by the square of the height in meters), mean blood pressure, blood and urinary cadmium levels, serum ferritin level, the presence of diabetes mellitus, smoking habits, alcohol intake, the use of analgesic and diuretic drugs, exposure to heavy metals at work, and residence in a rural as opposed to an urban area. Significant covariates of the renal measurements were traced by a stepwise regression procedure that ended when all the regression coefficients in the model were significant at the 5 percent level of probability. All adjustments for age included both a linear and a quadratic term for age.

\section{Results}

\section{Characteristics of the Subjects}

The characteristics of the 1981 subjects in the study group are summarized in Table 1. The subjects ranged in age from 20 to 88 years. Thirty-two percent (304) of the men reported possible exposure to heavy metals at work; the results of the study with respect to renal function were unchanged when we excluded these men. Among the men, 49 percent (470) were current smokers, and 37 percent (357) reported daily intake of alcohol; among the women these percentages were 35 (354) and 14 (140), respectively. Thirteen percent of the subjects (93 men and 162 women) reported regular use of analgesic drugs, 8 percent ( 47
Table 1. Demographic and Clinical Characteristics of the Study Subjects.*

\begin{tabular}{|c|c|c|}
\hline & $\operatorname{MEN}(N=965)$ & WOMEN $(\mathrm{N}=1016)$ \\
\hline Age $(\mathrm{yr})$ & $48 \pm 16$ & $48 \pm 16$ \\
\hline Body-mass index ${ }^{\dagger}$ & $25.5 \pm 3.6$ & $25.3 \pm 5.1$ \\
\hline \multicolumn{3}{|l|}{ Blood pressure (mm Hg) } \\
\hline Systolic & $133 \pm 16$ & $127 \pm 18 \ddagger$ \\
\hline Diastolic & $78 \pm 10$ & $76 \pm 9 \ddagger$ \\
\hline \multicolumn{3}{|l|}{ Blood measurements } \\
\hline Lead $(\mu \mathrm{g} /$ liter $)$ & $114(23-725)$ & $75(17-603) \ddagger$ \\
\hline $\begin{array}{l}\text { Zinc protoporphyrin } \\
(\mu \mathrm{g} / \mathrm{g} \text { of hemoglobin })\end{array}$ & $1.01(0.30-20.9)$ & $1.11(0.30-11.6) \ddagger$ \\
\hline Cadmium ( $\mu \mathrm{g} /$ liter $)$ & $1.14(0.10-14.6)$ & $1.11(0.10-9.10)$ \\
\hline \multicolumn{3}{|l|}{ Serum measurements } \\
\hline $\begin{array}{l}\beta_{2}-\text { Microglobulin } \\
(\mathrm{mg} / \mathrm{liter})\end{array}$ & $1.8 \quad(0.9-8.1)$ & $1.8 \quad(1.7-9.6)$ \\
\hline Creatinine (mg/dl) & $1.24(0.70-4.64)$ & $1.05(0.58-2.71) \ddagger$ \\
\hline $\begin{array}{l}\gamma \text {-Glutamyl transpepti- } \\
\text { dase (U/liter) }\end{array}$ & $14(2-252)$ & $9(2-335) \ddagger$ \\
\hline \multicolumn{3}{|l|}{ Urine measurements } \\
\hline Volume (liters/day) & $1.65 \pm 0.70$ & $1.66 \pm 0.74$ \\
\hline Creatinine (g/day) & $1.74 \pm 0.45$ & $1.19 \pm 0.31 \neq$ \\
\hline Cadmium $(\mu \mathrm{g} /$ day $)$ & $1.06(0.04-36.5)$ & $0.80(0.01-7.98) \ddagger$ \\
\hline \multicolumn{3}{|l|}{ Creatinine clearance $(\mathrm{ml} / \mathrm{min})$} \\
\hline Calculated§ & $80 \pm 24$ & $69 \pm 22 \ddagger$ \\
\hline Measured & $99 \pm 30$ & $80 \pm 25 \ddagger$ \\
\hline
\end{tabular}

*Plus-minus values are means $\pm \mathrm{SD}$; for logarithmically transformed distributions the geometric mean and range (in parentheses) are reported. To convert micrograms of cadmium to micromoles, multiply by 0.008897 ; to convert milligrams of creatinine per deciliter to micromoles per liter, multiply by 88.4 ; and to convert micrograms of lead to micromoles, multiply by 0.004826 .

$\dagger$ The weight in kilograms divided by the square of the height in meters.

$\$ \mathrm{P}<0.001$ for the comparison between sexes.

$\S$ According to the formula proposed by Cockeroft and Gault. ${ }^{11}$

men and 107 women) were using diuretic agents, and 3 percent (25 men and 29 women) were receiving treatment for diabetes.

\section{Factors Associated with Blood Lead and Zinc Protoporphyrin Levels}

Blood lead concentrations were higher in the men than in the women, but the opposite was found for zinc protoporphyrin (Table 1). Lead and zinc protoporphyrin levels depended to a large extent on age (Fig. 1). Both lead levels (89 vs. $95 \mu \mathrm{g}$ per liter [0.43 vs. 0.46 $\mu$ mol per liter], $\mathrm{P}=0.002)$ and zinc protoporphyrin levels (1.04 vs. $1.09 \mu \mathrm{g}$ per gram of hemoglobin, $P=0.02$ ) were lower in the rural areas than in the urban areas.

Stepwise multiple regression analysis revealed that blood lead levels were related to age (multiple partial $r$ for the linear and squared terms combined, 0.19 for the men and 0.41 for the women). In both sexes blood lead levels increased with smoking (partial $r=0.07$ for men and 0.18 for women), alcohol intake $(r=0.12$ and 0.14$)$, and serum $\gamma$-glutamyl transpeptidase $(r=0.07$ and 0.10$)$, whereas they were inversely correlated with body-mass index $(r=-0.07$ and -0.08). Among the men, blood lead levels were 29 percent higher on average in those who reported exposure to heavy metals at work (partial $\mathrm{r}=0.30$ ).

\section{Relation between Creatinine Clearance and Lead Exposure}

When the measured creatinine clearance rate was examined according to tertiles for blood lead or zinc protoporphyrin levels, there was a negative associ- 


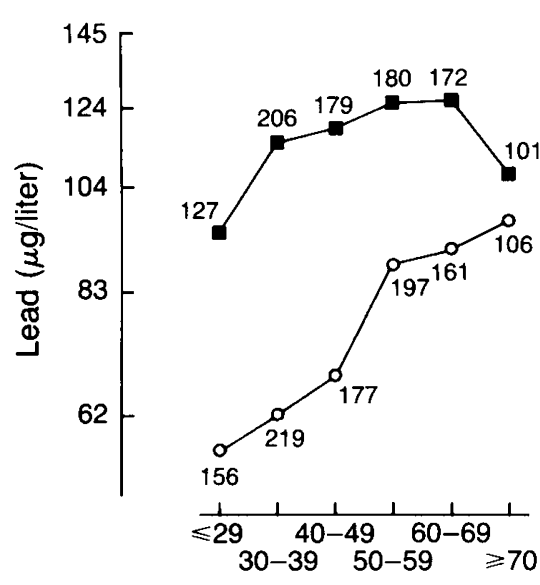

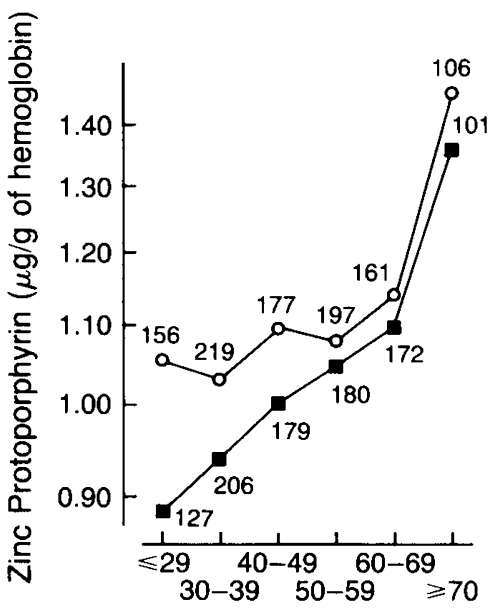

Age (years)

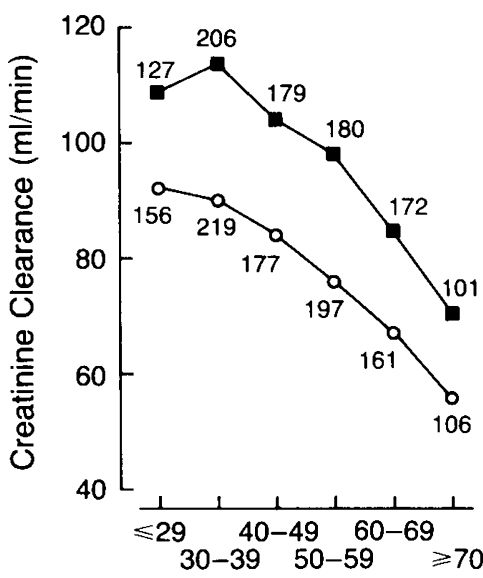

Figure 1. Blood Lead and Zinc Protoporphyrin Levels and Measured Creatinine Clearance, According to Age and Sex. Solid squares denote men, and open circles women. For each point, the number of subjects is shown. To convert micrograms of lead to micromoles, multiply by 0.004826 .

ation with lead in men and women, both before and after further stratification according to age (Table 2). The $\mathrm{F}$ value for a difference in the measured clearance with increasing blood lead and zinc protoporphyrin levels across the sex and age strata (Table 2) was 6.0 $(\mathrm{P}=0.003)$ for lead and $7.4(\mathrm{P}<0.001)$ for zinc protoporphyrin.

The measured creatinine clearance rate decreased with advancing age (Table 3 and Fig. 1), increased with higher body-mass index, and decreased with diuretic treatment. After adjustment for these covariates there was a significant inverse relation between the measured clearance rate and the blood lead concentration in both sexes (Table 3 and Fig. 2). A 10-fold increase in the blood lead level was associated with a decrease in the measured clearance rate of $10 \mathrm{ml}$ per minute in the men and $13 \mathrm{ml}$ per minute in the women (Table 3). When only the 30-to-69-year-old subjects were included in the analysis, the partial regression coefficients of the measured clearance rate on the log blood lead level (in milliliters per minute divided by micrograms per liter) were $-10.9 \pm 4.9(\mathrm{P}=0.03)$ in the men and $-11.8 \pm 4.7(\mathrm{P}=0.01)$ in the women. Similarly, after adjustment for age, body-mass index, and use of diuretic agents, a 10-fold increase in the zinc protoporphyrin level was associated with a decrease of $9 \mathrm{ml}$ per minute in the measured creatinine clearance rate in the men $(\mathrm{P}<0.05)$ and a decrease of $8 \mathrm{ml}$ per minute in the women $(\mathrm{P}=0.08$ ) (Table 3 and Fig. 2).

The correlations between the creatinine clearance rate and both the blood lead and zinc protoporphyrin levels were not altered by further adjustments for smoking habits, mean blood pressure, serum ferritin level, residence in an urban as opposed to a rural area, and blood or urinary cadmium level. With these additional adjustments (with urinary cadmium excretion used as the index of cadmium exposure), the partial regression coefficients on the log blood lead level were
$-19.5 \pm 4.3(\mathrm{P}<0.001)$ in the men and $-15.6 \pm 3.9$ $(\mathrm{P}<0.001)$ in the women, and the regression coefficients on the $\log$ zinc protoporphyrin level (in milliliters per minute divided by micrograms per gram of hemoglobin) were $-9.4 \pm 4.6(\mathrm{P}=0.04)$ and $-8.6 \pm$ $4.3(\mathrm{P}=0.04)$, respectively. Thus, the correlation between the blood lead level and the creatinine clearance rate was maintained after adjustment for the known influences of blood pressure and exposure to cadmium on renal function.

\section{Relation between Blood Lead Levels and Indexes of Renal Function}

There was a significant and positive relation between serum $\boldsymbol{\beta}_{2}$-microglobulin and blood lead levels in

Table 2. Measured Creatinine Clearance According to Sex, Age, and Blood Lead and Zinc Protoporphyrin Levels.*

\begin{tabular}{|c|c|c|c|c|c|c|}
\hline & \multicolumn{3}{|c|}{$\operatorname{MEN}(N=965)$} & \multicolumn{3}{|c|}{ WOMEN $(\mathrm{N}=1016)$} \\
\hline & $\begin{array}{c}\text { LOWEST } \\
\text { THIRD }\end{array}$ & $\begin{array}{l}\text { MIDDLE } \\
\text { THIRD }\end{array}$ & $\begin{array}{l}\text { HIGHEST } \\
\text { THIRD }\end{array}$ & $\begin{array}{l}\text { LOWEST } \\
\text { THIRD }\end{array}$ & $\begin{array}{l}\text { MIDDLE } \\
\text { THIRD }\end{array}$ & $\begin{array}{l}\text { HIGHEST } \\
\text { THIRD }\end{array}$ \\
\hline Lead $(\mu \mathrm{g} /$ liter $)$ & 72 & 114 & 184 & 48 & 72 & 118 \\
\hline \multicolumn{7}{|c|}{ Creatinine clearance $(\mathrm{ml} / \mathrm{min})$} \\
\hline Youngest third & 111 & 109 & 114 & 95 & 94 & 86 \\
\hline Middle third & 107 & 103 & 100 & 89 & 80 & 78 \\
\hline Oldest third & 85 & 80 & 81 & 67 & 67 & 64 \\
\hline All & 101 & 97 & 98 & 83 & 80 & 76 \\
\hline $\begin{array}{l}\text { Zinc protoporphyrin } \\
(\mu \mathrm{g} / \mathrm{g} \text { of hemoglobin })\end{array}$ & 0.74 & 1.02 & 1.44 & 0.80 & 1.06 & 1.59 \\
\hline \multicolumn{7}{|c|}{ Creatinine clearance $(\mathrm{ml} / \mathrm{min})$} \\
\hline Youngest third & 111 & 114 & 110 & 94 & 88 & 92 \\
\hline Middle third & 107 & 100 & 103 & 84 & 84 & 78 \\
\hline Oldest third & 87 & 82 & 77 & 68 & 68 & 61 \\
\hline All & 101 & 98 & 96 & 82 & 80 & 77 \\
\hline
\end{tabular}

*The blood lead and zinc protoporphyrin levels are geometric means, and the creatinine clearance values are arithmetic means. The $F$ value for a difference in the creatinine clearance rate across the sex and age strata was $6.0(P=0.003)$ for increasing lead levels and 7.4 $(\mathbf{P}<0.001)$ for increasing zinc protoporphyrin levels. To convert micrograms of lead to micromoles, multiply by 0.004826 . For lead levels, zinc protoporphyrin levels, and age, the subjects were divided into three equal groups: those with values below the 33 rd percentile, those jects were divided into three equal groups: those with values below the 33rd percentile, those
with values from the 33rd through the 66th percentile, and those with values above the 66 th percentile. 
Table 3. Determinants of the Measured Creatinine Clearance Rate.

\begin{tabular}{|c|c|c|c|c|}
\hline \multirow[t]{2}{*}{ VARIABLE* } & \multicolumn{2}{|c|}{ RELATION WITH LEAD } & \multicolumn{2}{|c|}{$\begin{array}{l}\text { RELATION WITH ZINC } \\
\text { PROTOPORPHYRIN }\end{array}$} \\
\hline & $\begin{array}{c}\text { MEN } \\
(\mathrm{N}=965)\end{array}$ & $\begin{array}{l}\text { WOMEN } \\
(N=1016)\end{array}$ & $\begin{array}{c}\text { MEN } \\
(\mathrm{N}=965)\end{array}$ & $\begin{array}{l}\text { WOMEN } \\
(\mathrm{N}=1016)\end{array}$ \\
\hline $\mathbf{R}^{2}$ & 0.27 & 0.25 & 0.26 & 0.25 \\
\hline Intercept & 86 & 99 & 66 & 79 \\
\hline \multicolumn{5}{|l|}{ Partial regression coefficient } \\
\hline Log lead ( $\mu \mathrm{g} /$ liter $)$ & $-9.51 \dagger$ & $-12.64 \ddagger$ & - & - \\
\hline $\begin{array}{l}\text { Log zinc protoporphyrin } \\
(\mu \mathrm{g} / \mathrm{g} \text { of hemoglobin })\end{array}$ & - & - & $-8.88 \dagger$ & $-7.72 \S$ \\
\hline Age $(y r)$ & $0.71 \neq$ & -0.05 & 0.439 & -0.229 \\
\hline Age squared & $-0.015 \ddagger$ & $-0.006 \ddagger$ & $-0.012 \ddagger$ & $-0.005 \ddagger$ \\
\hline Body-mass index & $1.76 \ddagger$ & $0.92 \ddagger$ & $1.72 \ddagger$ & $0.99 \ddagger$ \\
\hline $\begin{array}{l}\text { Log } \gamma \text {-glutamyl trans- } \\
\text { peptidase (U/liter) }\end{array}$ & $-6.38 \dagger$ & NSף & NSף & NS \\
\hline Diuretic therapy & $-8.77 \dagger$ & $-7.56 \ddagger$ & $-8.48 \dagger$ & $-8.04 \ddagger$ \\
\hline
\end{tabular}

*The linear and squared terms of age were tested simultaneously for entry into the regression model. Diuretic therapy was coded as 0 (not taking diuretic agents) or 1 (currently taking diuretic agents).

$\Varangle P \leqslant 0.05 . \quad \Varangle P \leqslant 0.001 . \quad \S P=0.08 . \quad$ INS denotes $P$ not significant.

the men and between serum $\boldsymbol{\beta}_{2}$-microglobulin and blood zinc protoporphyrin levels in both sexes (Table 4 ). In addition, serum creatinine was directly correlated with zinc protoporphyrin in the men (Table 4). Urinary volume was not correlated with the two indexes of lead exposure.

The measured creatinine clearance rate was in- versely correlated with blood lead and zinc protoporphyrin levels in the men and the women (Table 4). To exclude possible bias in the data due to inaccurate urine collections, creatinine clearance was also calculated from the serum creatinine level. The calculated clearance rate was inversely correlated $(\mathrm{P}<0.001)$ with both indexes of lead exposure (Table 4). A $10-$ fold increase in blood lead was associated with a decrease of $13 \mathrm{ml}$ per minute in the calculated clearance rate in the men and with a decrease of $30 \mathrm{ml}$ per minute in the women; the corresponding reductions associated with a 10 -fold increase in blood zinc protoporphyrin were 27 and $19 \mathrm{ml}$ per minute.

\section{Probability of Impaired Renal Function}

The fifth percentile for the measured creatinine clearance rate was $52 \mathrm{ml}$ per minute in the nondiabetic men who did not use analgesic or diuretic drugs and $43 \mathrm{ml}$ per minute in the women with similar characteristics. The 48 men and 62 women in whom creatinine clearance was below these values were classified as having impaired renal function.

In multiple logistic-regression analysis the probability of having impaired renal function (as defined above) increased with age (odds ratio for 70 vs. 30 years, 5.50; 95 percent confidence interval, 3.16 to $9.57 ; \mathrm{P}<0.01)$ and tended to be higher in subjects with
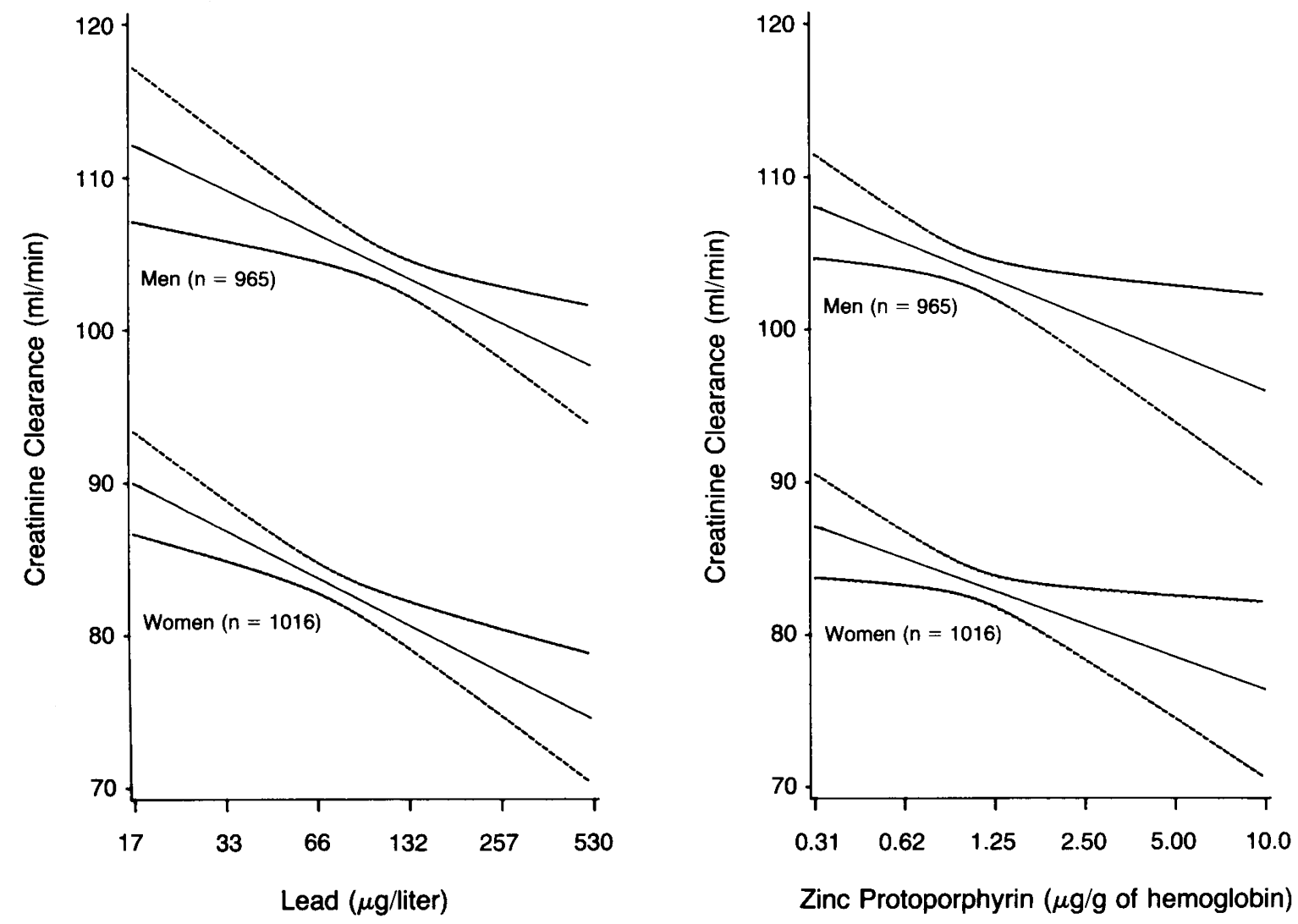

Figure 2. Relations between Measured Creatinine Clearance and Blood Lead and Zinc Protoporphyrin Levels after Adjustment for Age, Body-Mass Index, and Use of Diuretic Agents.

Broken lines represent 95 percent confidence intervals. The covariates were standardized as follows: 48 years of age, a body-mass index of 25.3, and nonuse of diuretic agents. To convert micrograms of lead to micromoles, multiply by 0.004826 . 
Table 4. Partial Regression Coefficients between Several Indexes of Renal Function and the Blood Lead and Zinc Protoporphyrin Levels.*

\begin{tabular}{|c|c|c|c|c|}
\hline \multirow[t]{2}{*}{ INDEX } & \multicolumn{2}{|c|}{ LOG LEAD } & \multicolumn{2}{|c|}{ LOG ZiNC ProtoporPHYRIN } \\
\hline & $\begin{array}{c}\text { MEN } \\
(\mathrm{N}=965)\end{array}$ & $\begin{array}{l}\text { WOMEN } \\
(\mathrm{N}=1016)\end{array}$ & $\begin{array}{c}\text { MEN } \\
(\mathrm{N}=965)\end{array}$ & $\begin{array}{l}\text { WOMEN } \\
(\mathrm{N}=1016)\end{array}$ \\
\hline \multicolumn{5}{|l|}{ Serum measurements } \\
\hline $\log \beta_{2}$-microglobulin (mg/liter) & $0.04 \pm 0.02 \dagger$ & $-0.01 \pm 0.02$ & $0.09 \pm 0.02 \ddagger$ & $0.06 \pm 0.02 \dagger$ \\
\hline Log creatinine $(\mathrm{mg} / \mathrm{dl})$ & $0.01 \pm 0.01$ & $0.01 \pm 0.01$ & $0.03 \pm 0.01 \dagger$ & $0.01 \pm 0.02$ \\
\hline \multicolumn{5}{|l|}{ Creatinine clearance $(\mathrm{ml} / \mathrm{min})$} \\
\hline Calculated§ & $-13.1 \pm 4.0 \ddagger$ & $-30.1 \pm 3.4 \ddagger$ & $-27.0 \pm 4.3 \ddagger$ & $-18.9 \pm 4.2 \ddagger$ \\
\hline Measured & $-9.5 \pm 4.4 \dagger$ & $-12.6 \pm 3.9 \ddagger$ & $-8.9 \pm 4.8 \dagger$ & $-7.7 \pm 4.4 \pi$ \\
\hline
\end{tabular}

*Values are partial regression coefficients $\pm S E$, adjusted for age, the square of the age, body-mass index, $\log \gamma$-glutamyl transpeptidase, presence of diabetes mellitus, and intake of analgesic and diuretic drugs. Lead was measured in micrograms per liter, and zinc protoporphyrin in micrograms per gram of hemoglobin.

$+P \leqslant 0.05$

$\ddagger P \leqslant 0.001$.

$\S$ According to the formula proposed by Cockcroft and Gault ${ }^{11}$

१P>0.05 but $\leqslant 0.1$.

diabetes (odds ratio, $2.11 ; 95$ percent confidence interval, 0.91 to $4.87 ; \mathbf{P}=0.08)$. By contrast, the risk of renal impairment did not significantly increase with the intake of analgesic drugs (odds ratio, 1.35; 95 percent confidence interval, 0.65 to $2.82 ; \mathrm{P}=0.42$ ) or diuretic agents (odds ratio, $0.61 ; 95$ percent confidence interval, 0.35 to $1.06 ; \mathrm{P}=0.08$ ).

With adjustments for age, the presence of diabetes, and the use of analgesic and diuretic drugs, the probability of having impaired renal function was directly correlated with the blood lead concentration. In the total study population the odds ratio associated with a 10 -fold increase in the blood lead level was 3.76 (95 percent confidence interval, 1.37 to $10.4 ; \mathrm{P}=0.01$ ).

\section{Discussion}

Lead exposure, estimated from blood lead or zinc protoporphyrin levels, was associated with a decrease in creatinine clearance in the general population. Because the urinary excretion of lead is not reduced unless renal failure is severe, ${ }^{12-15}$ these findings suggest that environmental lead exposure may impair renal function. The significant direct correlations between serum $\beta_{2}$-microglobulin and blood lead levels in the men and between serum $\beta_{2}$-microglobulin and zinc protoporphyrin levels in both sexes (Table 4) are compatible with the presence of glomerular dysfunction. ${ }^{7}$ However, because 10 to 40 percent of creatinine is secreted in normal subjects, ${ }^{16}$ the decrease in the creatinine clearance rate may also reflect diminished tubular secretion of creatinine. The impairment of renal function could not be explained by exposure to cadmi$\mathrm{um}^{3}$ or by elevated blood pressure. ${ }^{17}$

There is a large body of evidence suggesting that lead may cause proximal renal tubular dysfunction. Children with lead intoxication have aminoaciduria and glycosuria, and Fanconi's syndrome may develop. ${ }^{18}$ The decreased urinary excretion of uric acid in lead nephropathy may be partially explained by a lead-induced inhibition of urate secretion. ${ }^{19}$ Pregnant women with higher blood lead concentrations have inappropriately low serum erythropoietin levels. ${ }^{20}$ Histopathologically, lead nephropathy is characterized by the deposition of lead in the straight S3 segments of the proximal tubules. ${ }^{21}$ The glomeruli are usually normal or only nonspecifically affected, ${ }^{21}$ but this finding does not exclude glomerular dysfunction in vivo. The present findings are also in agreement with the results of mortality studies in Australia $^{22}$ and studies of working populations exposed to lead, ${ }^{23}$ in which there were more deaths from nephritis than expected. In the British Regional Heart Study, after allowing for the influence of alcohol consumption, there was a weak positive trend toward an increased serum urate concentration at a blood lead concentration above 370 $\mu \mathrm{g}$ per liter $(1.79 \mu \mathrm{mol}$ per liter $) .{ }^{24}$ By contrast, several studies of workers with blood lead concentrations below $700 \mu \mathrm{g}$ per liter $(3.38 \mu \mathrm{mol}$ per liter $)$ did not demonstrate an effect on renal function. ${ }^{25,26}$

The possibility that the inverse relation between creatinine clearance and lead exposure could result from a decrease in the renal excretion of lead when renal function is impaired cannot be ruled out. However, the lead content of bone in patients with chronic renal disease that is not due to lead exposure has been reported to be within the normal range, whereas bone lead was elevated in patients with chronic lead nephropathy. ${ }^{12,15}$ Campbell et al. measured blood lead concentrations in 40 subjects with varying renal function. ${ }^{13}$ The mean blood lead concentrations in these subjects were similar, suggesting that renal impairment itself does not raise blood lead levels. Among patients with essential hypertension, Batuman et al. found no significant differences in blood lead concentrations between those whose creatinine clearance rates averaged $94 \mathrm{ml}$ per minute and those whose rates averaged $29 \mathrm{ml}$ per minute. ${ }^{14}$

In our study, 24-hour urinary volume and creatinine excretion were similar to these measures in other population surveys, ${ }^{27}$ but they were slightly lower than in other reports in which only selected healthy subjects were studied while receiving standardized amounts of fluid and protein. ${ }^{28}$ The subjects in this study were carefully instructed in how to collect their urine, but the collections were not repeated and the samples were collected while the subjects continued their usual daily activities and dietary habits.

The validity of the present findings was supported by the observation that the well-known influences of sex, age, and body-mass index on creatinine clearance could be reproduced and by the fact that the correlations with the indexes of lead exposure were also found when the creatinine clearance rate was estimated from the serum creatinine level. ${ }^{11}$

The World Health Organization's Regional Office for Europe currently recommends that 98 percent of the adult population should have a blood lead level below $200 \mu \mathrm{g}$ per liter $(0.98 \mu \mathrm{mol}$ per liter $) .{ }^{29}$ The blood lead concentration exceeded this limit in 6 per- 
cent of our subjects, and it rose 35-fold from the lowest to the highest level (Table 1). Given this range, the risk of impaired renal function due to lead exposure would be nearly as great as the risk due to aging, which is generally considered to be important in clinical terms. Further studies are required, however, to exclude the alternative hypothesis that lead retention is a consequence of primary renal impairment.

We are indebted to the populations, general practitioners, and community authorities in the four study areas, without whose collaboration the study would not have been possible; to Dr. G. Vyncke, Provincial Health Inspector, Hasselt; and to Mrs. L. Gijsbers, Mrs. A. Hermans, Mr. J. Huysecom, Mrs. M.-J. Jehoul, Mrs. L. Lommelen, Mrs. V. Mariën, Mrs. O. Palmans, Mrs. C. Schraepen, Mrs. I. Tassens, Mrs. Y. Toremans, and Mrs. S. Van Hulle for expert technical assistance and assistance in the preparation of the manuscript.

\section{REFERENCES}

1. Bernard A, Lauwerys R. Cadmium in human population. Experientia $1984 ; 40: 143-52$

2. Wedeen RP, Maesaka JK, Weiner B, et al. Occupational lead nephropathy. Am J Med 1975;59:630-41.

3. Buchet J-P, Lauwerys R, Roels $\mathrm{H}$, et al. Renal effects of cadmium body burden of the general population. Lancet 1990;336:699-702

4. Staessen J, Yeoman WB, Fletcher AE, et al. Blood lead concentration, renal function, and blood pressure in London civil servants. $\mathrm{Br} \mathrm{J}$ Ind Med $1990 ; 47: 442-7$

5. Lauwerys R, Amery A, Bernard A, et al. Health effects of environmental exposure to cadmium: objectives, design and organization of the Cadmibel Study: a cross-sectional morbidity study carried out in Belgium from 1985 to 1989. Environ Health Perspect 1990;87:283-9.

6. Staessen J, Bulpitt CJ, Fagard R, Joossens JV, Lijnen P, Amery A. Salt intake and blood pressure in the general population: a controlled intervention trial in two towns. J Hypertens 1988;6:965-73

7. Karlsson FA, Wibell L, Evrin PE. $\boldsymbol{\beta}_{2}$-Microglobulin in clinical medicine. Scand J Clin Lab Invest Suppl 1980;154:27-37.

8. Bartels H, Böhmer M. Eine Mikromethode zur Kreatininbestimmung. Clin Chim Acta 1971;32:81-5.

9. Bernard AM, Lauwerys RR. Continuous-flow system for automation of latex immunoassay by particle counting. Clin Chem 1983;29:1007-11.

10. Persijn JP, van der Silk W. A new method for the determination of $\gamma$-glutamyltransferase in serum. J Clin Chem Clin Biochem 1976;14:421-7.
11. Cockcroft DW, Gault MH. Prediction of creatinine clearance from serum creatinine. Nephron 1976;16:31-41.

12. Emmerson BT, Lecky DS. The lead content of bone in subjects without recognized past lead exposure and in patients with renal disease. Australas Ann Med 1963;12:139-42.

13. Campbell BC, Elliott HL, Meredith PA. Lead exposure and renal failure: does renal insufficiency influence lead kinetics? Toxicol Lett 1981;9:1214.

14. Batuman V, Landy E, Maesaka JK, Wedeen RP. Contribution of lead to hypertension with renal impairment. N Engl J Med 1983;309:17-21.

15. Emmerson BT. Lead stores in patients with renal insufficiency. Nephron 1991;58:233-4

16. Hilbrands LB, Artz MA, Wetzels JFM, Koene RAP. Cimetidine improves the reliability of creatinine as a marker of glomerular filtration. Kidney Int 1991;40:1171-6.

17. Staessen J, Sartor F, Roels H, et al. The association between blood pressure, calcium and other divalent cations: a population study. J Hum Hypertens 1991;5:485-94.

18. Chisolm $\mathrm{JJ} \mathrm{Jr}$. Aminoaciduria as a manifestation of renal tubular injury in lead intoxication and a comparison with patterns of aminoaciduria seen in other diseases. J Pediatr 1962;60:1-17.

19. Emmerson BT, Mirosch W, Douglas JB. The relative contributions of tubular reabsorption and secretion to urate excretion in lead nephropathy. Aust N Z J Med 1971;1:353-62.

20. Graziano JH, Slavkovic V, Factor-Litvak P, Popovac D, Ahmedi X, Mehmeti $A$. Depressed serum erythropoietin in pregnant women with elevated blood lead. Arch Environ Health 1991:46:347-50.

21. Cramer K, Goyer RA, Jagenburg R, Wilson MH. Renal ultrastructure, renal function, and parameters of lead toxicity in workers with different periods of lead exposure. $\mathrm{Br}$ J Ind Med 1974;31:113-27.

22. A review of the evidence relating to lead as an aetiological agent in chronic nephritis in Queensland. Med J Aust 1934;1:600-6.

23. Sharp DS, Becker CE, Smith AH. Chronic low-level lead exposure: its role in the pathogenesis of hypertension. Med Toxicol 1987;2:210-32.

24. Pocock SJ, Shaper AG, Ashby D, Delves T, Whitehead TP. Blood lead concentration, blood pressure, and renal function. BMJ 1984;289:872-4.

25. Buchet JP, Roels H, Bernard A, Lauwerys R. Assessment of renal function of workers exposed to inorganic lead, cadmium or mercury vapor. J Occup Med 1980;22:741-50.

26. Gerhardsson L, Chettle DR, Englyst V, et al. Kidney effects in long term exposed lead smelter workers. Br J Ind Med 1992;49:186-92.

27. Intersalt Cooperative Study Group. Intersalt: an international study of electrolyte excretion and blood pressure: results for 24 hour urinary sodium and potassium excretion. BMJ 1988;297:319-28.

28. Levey AS, Perrone RD, Madias NE. Serum creatinine and renal function. Annu Rev Med 1988;39:465-90.

29. World Health Organization Regional Office for Europe. Air quality guidelines for Europe. WHO regional publications, European series no. 23. Copenhagen, Denmark: World Health Organization, 1987:242-61. 